\title{
Europeanization and EU-Turkey Relations: Three Domains, Four Periods
}

\author{
Başak Alpan
}

\subsection{INTRODUCTION}

The concept of Europeanization has by now become one of the most versatile concepts of European studies. From the early 1990s, scholars have used the term as a tool for the analysis of different aspects of the transformative power of European integration (see Cowles et al., 2001; Kohler-Koch \& Eising, 1999; Featherstone \& Radaelli, 2003), as well as for studying various facets of the transformation triggered by European integration in the member states of the European Union (EU) and candidate states. Since the 1999 Helsinki decision, when Turkey was granted EU candidacy, Europeanization has been one of the leading

B. Alpan $(\bowtie)$

Department of Political Science and Public Administration, Middle East Technical University (METU), Ankara, Turkey e-mail: balpan@metu.edu.tr 
conceptual approaches ${ }^{1}$ through which EU-Turkey relations have been examined. According to the seminal conception of the term by Radaelli, Europeanization is

a process of construction, diffusion and institutionalization of formal and informal rules, procedures, policy paradigms, styles, ways of doing things, and shared beliefs and norms which are first defined and consolidated in the making of EU decisions and then incorporated in the logic of domestic discourses, identities, political structures and public policies. (Radaelli, 2003: 30)

One of the most extensive analyses of the concept is provided by Olsen, who focuses on two key dimensions of institutional change: changes in 'political organization [and] changes in structures of meaning and people's minds' (Olsen, 2002: 926). Thus, the focus of the Europeanization approach is to find out how the European level affects domestic politics, policies, and polity, and whether Europeanization leads to convergence or divergence between the European level and the domestic level in a particular country. This process of change applies to various domains that impact the domestic level and to various degrees (substantive scope) in EU member countries, EU candidate states, and neighboring countries (territorial scope), including Turkey. ${ }^{2}$

As far as the EU-Turkey dialogue is concerned, Europeanization could be explained as the transformation of the way in which Turkish institutions, policies and 'way of doing things' are constructed and implemented so as to ensure Turkey's overall convergence towards EU standards. In turn, de-Europeanization can be understood as 'the loss or weakening of the EU/Europe as a normative/political context and as a reference point in domestic settings and national public debates' in Turkey (Aydın-Düzgit \& Kaliber, 2016: 5).

\footnotetext{
${ }^{1}$ The general consensus in the literature is that Europeanization is not a new theory, nor an ad hoc approach, but rather a way of organizing and orchestrating existing concepts, and that 'Europeanization should be seen as a problem, not as a solution'. By the same token, Europeanization is not the explanans (the solution, the phenomenon that explains the dependent variables), but the explanandum (the problem that needs to be explained). In this respect, I will be using the term 'approach' or 'concept' (rather than 'theory') with regard to Europeanization throughout the paper (see Radaelli, 2004: 1).

${ }^{2}$ For the distinction between territorial and substantive aspects of Europeanization see Lenschow (2006: 59-61).
} 
The 'territorial scope' of Europeanization refers to the space within which the EU has impact. Territorial scope focuses on the question of whether the EU impact remains limited to the EU member states or whether it also includes non-member states such as Turkey. Besides the territorial scope of the concept, Europeanization is also assessed in the literature in terms of its influence across the interrelated polity, policy and politics domains. The 'polity' domain covers national governance systems, administrative structures and the executive, legislative, and judicial authorities of the country in question. The 'policy' domain refers to the broader legislative framework, such as the economy, agricultural, justice, and home affairs policies of the country in question. Finally, the domain of 'politics' concerns the political parties, political actors, elections, and public opinion of the country (Bache \& Jordan, 2006). The shifts in the domestic identities and discourses are also taken under the rubric of politics in this chapter, given that the political science debates, at least from the early 1980s onwards, were an extension of its scope. Here, the domain includes not only formal institutions but also informal political processes, identities, discourses, and power negotiations in the political realm (Bache \& Jordan, 2006).

This chapter aims to trace the theoretical underpinnings of the Europeanization approach and to explore the Turkish case by referring to different mechanisms and variants of Europeanization through an analysis of these domains in four different periods between 1963 and early 2020. These periods are in line with major milestones of EU-Turkey relations (Hauge et al., 2016; Eralp, 2009; see also Turhan \& Reiners, Chapter 1). The underlying question is the extent to which the Europeanization approach constitutes a useful tool to grasp and understand EU-Turkey relations, and how it helps make sense of phases of convergence and divergence between the two parties.

\subsection{EUropeanization StUdies AND THE Research Agenda on Turkey}

Although the Europeanization approach has been part of the core research agenda since the 1990s, the analytical focus of the literature has shifted throughout generations. The literature on Europeanization initially aimed to explain the development at the European level, focusing on distinct structures of governance specializing in the creation of authoritative European rules (Cowles et al., 2001: 3) and their impact on 
policies, politics, and polities at the domestic level in member states (Börzel \& Risse 2003: 59). The early examples of the literature aimed to define the relationship between the European and the domestic level in a top-down manner, whereby the domestic is determined by the European level. This earlier group of studies, also dubbed as 'first-generation' (see Bache \& Marshall, 2004) Europeanization literature or 'Europe-as-fixity' (Alpan, 2014: 69) studies, depicted 'traditional Europeanization' (Moga, 2010), and defined 'Europe' as a fixed, categorical, and teleological entity to which the domestic level has to adjust.

By the late 1990s and early 2000s, Europeanization was reconceptualized as a bottom-up process encompassing different aspects of society and politics in candidate states and in third countries. A bottom-up approach to the study of Europeanization '[...] start[ed] and finish[ed] at the level of domestic actors' (Radaelli \& Pasquier, 2006: 11). With Eastern enlargement, in particular, research on the EU's 'transformative power' (Börzel \& Risse, 2009) shifted from membership to the accession context, and so-called 'enlargement-led Europeanization' (Moga, 2010: 6) started to focus on the domestic sphere (Schimmelfennig et al., 2006). This 'second-generation' Europeanization literature (Schimmelfennig \& Sedelmeier, 2005) put the role of conditionality ${ }^{3}$ and the Copenhagen criteria at the center of the analysis, which acted as a catalyst for domestic reforms, such as in the fields of politics, law, and education, in candidate states.

Turkey's EU integration was understood and studied within the context of second-generation Europeanization literature, especially in the aftermath of the Helsinki decision, with a focus on normative aspects of integration, identity constructions, and domestic conditions regarding candidate countries. Several studies examined Europeanization within the context of Turkey's EU accession by comparing it with the Central and Eastern European countries (Kubicek, 2003; Schimmelfennig et al., 2003) and with the other candidates in the Western Balkans (e.g., Noutcheva \& Aydın-Düzgit, 2012). However, most scholars used the term to examine the democratic change in Turkey's political regime as a result of political reforms in order to meet the Copenhagen criteria.

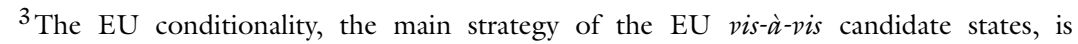
defined as a 'reactive reinforcement' by the EU. It checks fulfilment or non-fulfilment of the EU's conditions, imposed on the candidate states without punishing non-compliant candidates. See Schimmelfennig et al. (2002: 2) for a detailed discussion. 
There has also been considerable interest among Turkish academics on the impact of Europeanization on specific policy areas such as foreign policy (Terzi, 2012; Günay \& Renda, 2014), minority policy (Yılmaz, 2017; Grigoriadis, 2008a; Atikcan, 2010), gender policy (Özdemir, 2014; Kılıç, 2008; Dedeoğlu \& Elveren, 2008), and migration policy (Bürgin, 2016; İçduygu, 2015). Beyond that, the second-generation Europeanization research agenda also included the study of identities (Rumelili, 2008; Nas, 2012), discourses (Aydın-Düzgit, 2016; Alpan, 2014), and public debates (Kaliber, 2016).

\subsection{Europeanization in Turkey: Four Phases}

In line with historical milestones that framed the flow of EU-Turkey relations and the dominant feature of the Europeanization process during the respective periods, this chapter scrutinizes Europeanization in Turkey over four phases. It does so on the basis of an analysis across the domains of polity, policy, and politics. The first period, 'Europeanization as rapprochement', covers the years between 1959 and 1999 and thus the time from Turkey's first application for associate membership until the European Council's decision to grant Turkey the status of an accession candidate. The second period, 'Europeanization as democratic conditionality', between 2000 and 2005 lasts up until the launch of accession negotiations. The third period is dubbed 'Europeanization as retrenchment'. It covers the period from 2006 until the Justice and Development Party's (AKP) landslide electoral victory in 2011 , when the party consolidated its power position and when the pace of EU reforms and the overall credibility of the EU substantially dropped. The final ongoing period, 'Europeanization as denial', includes the developments until 2020 and signifies the failing credibility, yet ensuing resonance, of Turkey's potential EU accession.

\subsubsection{Europeanization as Rapprochement (1959-1999)}

\subsubsection{Polity: The European Economic Community as a Natural Extension of Western Organizations}

In the 1960s and 1970s, for the Turkish political establishment, European Economic Community (EEC) membership was nothing but 'a logical extension of Turkey's inclusion in other Western organizations, since it was seen as the economic dimension supplementing and cementing the 
Western alliances' (Eralp, 1993: 26). Therefore, Turkey's relations with the EEC in this period did not lead to a fundamental shift in state-society relations and were mainly based on economic and security narratives (Hauge et al., 2016: 11). During this period, there was also no substantial institutional change in Turkey associated with the EEC. The most important development was Turkey's application for association to the EEC in 1959 and the signing of the Agreement Creating an Association between the EEC and Turkey, famously known as the Ankara Agreement. It constituted the first contractual relationship between the two sides (Aydın-Düzgit \& Tocci, 2015: 10). The agreement primarily envisaged the establishment of a Customs Union (CU) between the EU and Turkey in three stages. It also stated that the parties should examine the possibility of Turkey's EEC accession 'as soon as the operation of this Agreement has advanced far enough to justify envisaging full acceptance by Turkey of the obligations arising out of the Treaty establishing the Community' (EEC-Turkey Association Agreement, 1963: 15).

The institutional structure established by the Agreement consisted of an Association Council, where top-level officials from both sides would regularly meet; an Association Committee, to assist the work of the Council; and a Joint Parliamentary Committee, bringing together Turkish and European parliamentarians (Aydın-Düzgit \& Tocci, 2015: 11). The establishment of an EU-induced polity change after the Ankara Agreement came first, but it was followed by other institutions, such as the Capital Markets Board in 1981, which aimed to achieve liberalization and harmonization with the European economy. Although relations deteriorated during the 1970s due to financial crises in Europe and Turkey, and Turkey's intervention in Cyprus in 1974 and its subsequent decision to unilaterally freeze relations and economic obligations with the Community in 1978, the institutional structure created by the Ankara Agreement continued to form the institutional backbone of the CU and EU-Turkey relations outside the enlargement context. The final stage of the CU with the EU was reached by Decision No. 1/95 of the Association Council (EC-Turkey Association Council, 1996), and the CU entered into force on 31 December 1995.

\subsubsection{Policy: First Steps in EEC-Induced Policies}

Europeanization in terms of policy change was less significant in the first period. Most of the policy changes were realized, with Turkey's fulfillment of its obligations stemming from the Association Agreement. Accordingly, 
after the completion of the CU, Turkey aligned its customs tariff with the Common Customs Tariff imposed on third countries (EC-Turkey Association Council, 1996: Article 13). This also meant the alignment of Turkey's commercial policy, customs law, competition law, taxation law, and intellectual property law with the EU acquis (European Commission, 2020).

Within the context of the military memorandum of 1971 and the coup d'état in Turkey of 1980, EU institutions increasingly criticized the democratic deficits and human rights violations (Hauge et al., 2016: 13). The European Parliament (EP) issued eleven resolutions regarding human rights violations between 1980 and 1985, criticizing Turkey's death penalty, use of torture, and mass trials against demonstrators (Balfe, 1985: 47; Hauge et al., 2016: 13). In return, Turkey accepted the right of individuals to petition the European Court of Human Rights (ECHR) in January 1987, and the compulsory jurisdiction of the ECHR in September 1989 (ECHR, 2010: 52). The early signals of the EEC's democratization agenda regarding Turkey did not, nevertheless, lead to any significant policy change in Turkey in the realm of democracy and human rights in the 1990s. Despite the EEC's human rights-based approach, Europeanization in this period was generally an extension of the normalization and economic liberalization in Turkey that came after the 1980 coup. Turkey's first application for full membership in 1987 and its rejection in 1989 should be understood within this context.

The EEC's focus on human rights and democratization in Turkey continued in the 1990s. However, the confinement of democratization to the economic realm in the 1980s was now increasingly replaced by democratization attempts within the political sphere. To give one example, in March 1994, the EP harshly criticized the removal of the parliamentary immunity of deputies of the pro-Kurdish Democracy Party (DEP), although this did not resonate in Turkish politics. Accordingly, the Luxembourg European Council of December 1997, again denied Turkey full candidate status on the grounds that 'the political and economic conditions allowing accession negotiations to be envisaged are not satisfied' (European Council, 1997: para. 31). However, despite Turkey's lack of progress in the fulfillment of the political criteria, just two years after the Luxembourg decision, in December 1999 the Helsinki European Council confirmed Turkey's candidate status in the wake of the strong support of the then German chancellor Gerhard Schröder and from the USA (Park, 2000: 36). 


\subsubsection{Politics: 'Europe' as an Identity Marker in Turkish Politics}

While Europeanization in this first phase significantly affected economics and institutions, we also see that the European level impacted the negotiation of collective identities on the various levels of subjective affiliations. In continuation of the tradition in Turkish politics since the eighteenth century, political actors used 'Europe' as an identity marker in their public discourses during this period. Turkish media, business, and the majority of the political elite highlighted the symbolic and political importance of joining the EEC, expressed as Turkey's determination to be a permanent member of the 'European society of states', an ideal prescribed by the founder of the republic, Mustafa Kemal Atatürk. Similarly, despite its overwhelmingly economic character, the signing of the Association Agreement in 1963 was described in the Turkish press as the 'reaffirmation of Turkey's Western identity' and 'Europeanness' (Çalış, 2015: 125; Kaliber, 2013: 11). In the 1980s, Turkey perceived that its Western identity was approved and its place in the East-West divide of Cold War politics was consolidated through Europeanization. During the November 1987 general election campaign, the election motto of the Motherland Party (Anavatan Partisi, ANAP) under the leadership of Turgut Özal was 'Turkey: a European country which is able to catch up with the era' (Alpan, 2015: 13). Similarly, after the CU Agreement, prime minister Tansu Çiller referred to the CU as the obvious outcome of Turkish efforts to include Turkey in the 'European family' (Neziroğlu \& Yllmaz, 2013: 7071).

At the same time, Turkey's EEC association application also generated resentment in political circles. On the one side, the Islamist political movements of the late 1960s conceived Turkey's integration with the EEC 'as the last stage of the assimilation of Turkey's Islamic identity into the Christian West' (Güneş-Ayata, 2003: 216). The rising pro-Islamic party of the time, MSP (Milli Selamet Partisi, National Salvation Party), characterized the EEC as a 'Christian Club'. Economically, these parties claimed that the EEC would weaken domestic industries and make Turkey a prey to 'Western imperialism' (Güneş-Ayata, 2003: 216). On the other side, the Left's motto 'They are the partner, we are their market' ${ }^{4}$ pointed to the economic asymmetry between Turkey and the EEC.

\footnotetext{
${ }^{4}$ In Turkish, the word 'ortak' means both 'partner' and 'common'. Hence, with this slogan, the detrimental and 'colonizing' effects of the Common Market for Turkey and Turkish economic independence were emphasized.
} 
While the excitement of the CU positively affected political actors' opinions about the EEC/EU in the first half of 1990s, the second half of the 1990s was marked by intense domestic and external political developments, such as consecutive coalition governments getting into power, the 28 February process, ${ }^{5}$ the Imia crisis, ${ }^{6}$ the Cypriot acquisition of Russian S-300 missiles, and Cyprus's prospective EU membership. The picture in Turkey became even more complicated with the 1997 European Council decision in Luxembourg. Both the Turkish government and the opposition parties were critical that EU accession talks could not start. In this context, Turkey's Foreign Minister at that time, İsmail Cem, stated that 'Turkey is European anyway. [...] We do not need anyone's approval for this' (Erdoğan et al., 2008: 47). Not surprisingly, the political tide completely reversed in the aftermath of the Helsinki decision, when Prime Minister Ecevit signaled, 'Europe cannot exist without Turkey, and Turkey cannot exist without Europe' (Demirtaş, 1999).

\subsubsection{Europeanization as Democratic Conditionality (2000-2005)}

\subsubsection{Polity: Transformation of the Strong State Tradition}

The anchoring of Turkey to EU conditionality brought about by the Helsinki decision triggered a shift in state-society relations throughout the Turkish political landscape. Turkey's introduction of several constitutional reform packages between 1999 and 2004 was perceived as a direct challenge to the traditionally strong state structure (Glyptis, 2005). Historically, in Turkey, the state, rather than the government, constituted 'the primary context of politics' (Keyman \& Koyuncu, 2005: 109). This shift away from the state emerged within the broader context of cosmopolitan democratization in the late 1980s and 1990s, which anchored citizenship, rights, and freedoms in the international context rather than in the nation-state (Rumford, 2003).

The era of democratic conditionality ushered in the introduction of basic freedoms such as the freedom of thought and expression, the

\footnotetext{
${ }^{5}$ The National Security Council during its meeting on 28 February 1997 forced the pro-Islamist Welfare Party (RP) to withdraw from government due to its anti-secular activities. This development is known as a 'postmodern coup' in Turkish public discourse and is dubbed as the ' 28 February process' in Turkish politics.

${ }^{6}$ In 1996, Imia, a pair of uninhabited Greek islets, was at the epicenter of a rapid escalation that brought Greece and Turkey to the brink of war.
} 
prevention of torture, strengthening of democracy, and civilian authority (Republic of Turkey Ministry of Foreign Affairs, 2007). However, the civilianization process of Turkish politics did not necessarily equal democratic consolidation within the country (Güney, 2015). The AKP government claimed to need 'the protection of democratic rights and liberties' more than any other political group in Turkey, specifically in order to survive in the Turkish secular context (Hale \& Özbudun, 2010: 10). Accordingly, legislative measures in this period that intended to civilianize politics 'helped solidify the AKP's position vis-a-vis the secular military via lessening the latter's political influence' (Saatçioğlu, 2014: 91). The most important among these were the changes that concerned the role and structure of the National Security Council (MGK), an essential state institution, established in 1961, that strengthened the role of the military in politics. The October 2001 amendments to the constitution increased the number of civilians in the MGK and reduced the power of its decisions to that of simple recommendation (Cizre, 2003: 222).

In this period, another noteworthy EU-induced institutional change was the establishment of a Secretariat General for EU Affairs in 2000 to ensure internal coordination and harmonization in the preparation of Turkey for EU membership. In line with the economic criteria of the Copenhagen criteria, the liberalization of the markets and harmonization with the CU continued during this period. The establishment of the Turkish Accreditation Agency (1999), the Energy Market Regulatory Authority (2001), the Turkish Sugar Authority (2001), the Tobacco and Alcohol Regulatory Authority (2002), and the Public Procurement Authority (2002) all contributed to the Europeanization of Turkey's institutions (Erdenir, 2015: 28-29), since these regulatory and supervisory institutions aimed to harmonize the market with European and international standards.

\subsubsection{Policy: Policy Reforms to Meet EU Accession Criteria}

Turkey's candidacy status created pressure on the country to adopt EU rules and resulted in comprehensive reforms between 1999 and 2004. The main impact of the 1999 Helsinki decision was of the introduction of a pre-accession strategy for Turkey. This strategy included providing assistance to Turkey to ensure a faster adaptation to the EU acquis through several programs and funding schemes. In order to 'participate in Community programs and agencies and in meetings between candidate 
States and the Union in the context of the accession process' (European Council, 1999), Turkey had to undertake a substantial degree of democratization and human rights reforms, which rendered reform synonymous with Europeanization. Some of those reforms were directly related with the obligations of the $\mathrm{CU}$ and functioning of the free market, such as the amendment of competition policy in 2002 and the introduction of the Public Procurement Act in 2003. Turkey's ambitious structural reform program of 2001, with the aim of laying a foundation for sustainable growth, can also be interpreted as laying the foundations of harmonization with the European and international economy (Dutz et al., 2005: $283)$.

Other reforms had a wider resonance in terms of compliance with the Copenhagen criteria and would fall more within Chapter 23 (Judiciary and Fundamental Rights) and Chapter 24 (Justice, Freedom, and Security) of the EU acquis. In 2001, the Turkish parliament was engaged in the most pervasive constitutional change of the Republican era, as 34 articles of the constitution of 1980 were amended to meet the EU's demands with regard to civil-military relations. The amendments were a part of the so-called 'silent revolution' between 1999 and 2005 (Aydın-Düzgit \& Tocci, 2015: 6). Examples include the amendment of the Press Law, the Law on Political Parties, the Law on Associations, the Law on Meetings and Demonstration Marches, the Law on Civil Servants, the Law on the Establishment of and Proceedings at the State Security Courts (Republic of Turkey Ministry of Foreign Affairs, 2007: 6). These laws were deemed a fundamental step toward meeting the Copenhagen criteria in the 2002 progress report of the Commission. The Turkish government also revised the Civil Law in 2001, Labor Code in 2003, and Penal Code in 2005. The 2004 constitutional amendment is particularly important in Turkey's Europeanization process with a view to the change in Article 10 stating that Turkey's international obligations are superior to Turkish law. This was a radical step in transitioning the Turkish state's traditional definition of sovereignty in preparation for EU accession (Müftüler-Baç, 2016a: 5).

The alignment of Turkey's foreign policy with EU standards commenced in this period in a parallel fashion (see also Torun, Chapter 13). To illustrate, starting from 2002, the Turkish Minister of Foreign Affairs began to attend the so-called 'Gymnich Meetings', informal meetings of the EU foreign ministers (Müftüler-Baç, 2016b: 99). Similarly, in view of the Helsinki European Council conclusions and 
the Accession Partnership document, which linked Turkey's EU membership to resolution of its border conflicts with Greece, the two states agreed to cooperate on various issues, such as tourism promotion, the fight against terrorism, the removal of landmines along the border, irregular migration, and trade and environmental issues (Çelik \& Rumelili, 2006: 218).

Against this background, at its meeting in December 2004, the European Council decided that Turkey sufficiently fulfilled the criteria to open accession negotiations. The EU opened membership negotiations with Turkey in October 2005 and adopted a negotiating framework to outline negotiations in the 35 acquis chapters (European Commission, 2005).

\subsubsection{Politics: Europe as Everybody's Project}

During the post-1999 period, 'Europe' held the utmost salience and significance for political actors and institutions. There was almost no political party that did not possess an opinion on Europe in its discourse or party program. The EU was also a significant element of identity negotiations for political actors. During the coalition government of the Democratic Left Party (DSP), the Motherland Party (ANAP), and the Nationalist Action Party (MHP) from 1999 to 2002, as well as under the following AKP government, 'Europe' had an apolitical, natural, and consensual connotation, and emerged as a common platform bringing everyone together (Alpan, 2014: 74). As stated by İsmail Cem, 'Europe is not an issue of controversy but an issue of compromise' (Radikal, 2002a) and 'an extra-political party issue' (Radikal, 2002b). This consensual and non-ideological tone was frequently used by the AKP. In his first speech after the launch of the EU negotiations, Recep Tayyip Erdoğan, then AKP party leader, pointed to the 'natural' character of Turkey's European project, neutralizing the internal contradictions of Turkish society (as quoted in Yetkin, 2005). He also considered that for the '40-year-old European dream of 70 million' to come true, Turkey should be accepted as an EU candidate (as quoted in Radikal, 2004). This consensual tone was also reflected in public opinion. In a poll in which respondents were asked whether they would vote for or against Turkey's bid for full membership in the EU if a referendum were held in 2002, 64\% of the respondents indicated that they would vote for EU membership, whereas $30 \%$ said that they would vote against it (Çarkoğlu, 2003: 172).

The Europeanization process also drew new, favorable attention toward minorities in Turkey. After the European Commission's 2004 
progress report for Turkey had designated the Kurds and Alevi people as minorities (European Commission, 2004), 'Europe' emerged as a keyword for minorities and multiple identities (i.e., simultaneous identification with Kurdish identity and Turkish citizenship). Right after the Helsinki Council, the famous motto 'the way to the EU passes through Diyarbakır' (as cited in Munyar, 2002) ${ }^{7}$ was put forward by Mesut Yllmaz, then deputy prime minister. Business circles also showed similar support for EU-related democratic reforms. The Turkish Industry and Business Association (TÜSİAD) played an active role in lobbying in Brussels before the Helsinki Summit and pressed for the resolution of highly controversial issues such as the extension of cultural rights and the Cyprus dispute (Öniş, 2003: 19).

That said, the EU reforms also triggered an anti-reform reaction across the political landscape. For instance, according to Tuncer Kulınç, then Secretary General of the MGK, the EU posed a 'danger' to Turkey, with its hidden agenda and demands for 'unilateral concession' (as cited in Radikal, 2003). According to this line of thought, the EU emerged as a body that created social cleavage where it had not previously existed. This idea also found resonance, to some extent, among the general public. The reform package ratified in 2002 on the abolition of the death penalty, for example, was supported by only 38\% of the public (Çarkoğlu, 2003: 187). All in all, the EU penetrated domestic debates, and political actors' references to Europe drew the contours of the political domain during this period. The EU was the lingua franca of politics so that each and every political identity had to talk that language and make the EU a reference point in order to assert its location within politics (Alpan, 2014: 69).

\subsubsection{Europeanization as Retrenchment (2006-2011)}

\subsubsection{Polity: Focus on State-Society Relations}

The picture of EU-Turkey relations started to change after 2005. A new Ministry of EU Affairs was established under the auspices of the first EU Minister, Egemen Bağış. There was an institutional focus on the EU perspective, and selective institutional reforms were carried out. However, these changes mainly relied on popular support to legitimize reforms in sensitive areas, such as in civil-military relations (Y1lmaz, 2016: 93).

\footnotetext{
${ }^{7}$ Diyarbakır in South-East Turkey holds the largest Kurdish population of any Turkish city.
} 
While civil-military relations had undergone many reforms since the post1980 period, the government still chose to retain some of the infamous remnants of the 1980 coup, such as the High Education Board YÖK ( Yükseköğretim Kurulu), which exercises significant government control over universities (Noutcheva \& Aydın-Düzgit, 2012: 70).

A similar situation was seen in the area of judicial reform. In August 2009, the government announced the Judicial Reform Strategy and put its main provisions to the public vote in the 2010 referendum. The amendments were presented as democratizing the judiciary and making it more responsive to society's demands by diversifying the background of the members of the Constitutional Court and by widening the composition of the High Council, which determines the career paths of judges and prosecutors. But these amendments were criticized for retaining substantial provisions that compromised judicial independence, in particular with regard to the powers of the Minister of Justice in the High Council (Noutcheva \& Aydın-Düzgit, 2012: 70). These developments, which culminated in the 2010 constitutional changes, contributed to the primacy of the executive over the legislative and the judiciary, which was identified by some as the beginning of the so-called 'de-Europeanization' trend in Turkish politics (Saatçioğlu, 2016: 136).

\subsubsection{Policy: Selective Europeanization}

Formally speaking, Europeanization was still at the top of the agenda in this period. For instance, 2008 was proclaimed the 'European Year' by the AKP, and in early 2009 the Turkish parliament passed the long-overdue 'National Programme for the Adoption of the Acquis', a blueprint for the reforms needed to gain full membership of the EU. Nevertheless, what characterized this period was the dramatic decrease in the number of legal amendments (Yilmaz, 2016: 90). So-called 'selective Europeanization' came to the forefront, in which the government cherry-picked which areas and which issues within these areas to reform (Y1lmaz, 2016: 90-94). For instance, as a part of the Ninth Reform Package, minority protection was further strengthened by adopting new laws such as the Law on Foundations and implementing minority protection rules (e.g., the launch of Turkish Radio Television 6 broadcasting in Kurdish). In this period, some elements of the controversial Article 301 were also amended in line with the strong social pressure from civil society and the EU. Article 301 of the Turkish Penal Code had penalized those 'who explicitly insult Turkishness, the Republic, or Turkish Grand National Assembly'. According 
to the new, less restrictive wording, Article 301 penalized 'insulting the Turkish nation' and required the permission of the Minister of Justice to file a case.

However, despite these reforms many problematic issues for minority protection were untouched, such as restrictions on the use of minority languages in political life (Yllmaz, 2014: 245). Rather than pursuing a comprehensive EU-triggered reform agenda, the government carried out significant yet sparse reform attempts congruent with its own political agenda. Starting in 2005, in parallel with the relaunch of Kurdistan Workers' Party (PKK) terrorism and rising nationalist movements, Turkey also witnessed the delimitation of fundamental rights and freedoms, especially after the amendments made to the Anti-Terror Law in 2006 (Aytar, 2006). The 2010 constitutional referendum paved the way for the concentration of power in the hands of the executive, and undermined the independence of the judiciary (Özbudun, 2015).

On the foreign policy front, Turkey's participation in the EU-led operations that had made use of NATO assets since 2003 made it possible for the country to continue its alignment with the Common Foreign and Security Policy of the EU during this period (see Torun, Chapter 13). Active Turkish participation in the NATO missions in Afghanistan, in the UN Interim Force in Lebanon in 2006, as well as in the EU-led operations in the Balkans indicated 'a Europeanization of foreign policy where Turkey demonstrated its ability as a team player for the EU' (MüftülerBaç \& Gürsoy, 2010: 412). However, toward the end of this period, Turkey started to become less inclined to comply with the EU's foreign policy parameters. Ankara's stance on the Iranian nuclear deal at the June 2010 United Nations Security Council and its response to NATO's intervention in Libya in 2011 indicated that Turkey had started to follow its own foreign policy options, rather than acting in line with European and American positions (Müftüler-Baç, 2016b: 99).

\subsubsection{Politics: 'Europe' No Longer the Lingua Franca}

After 2005, 'Europe' no longer emerged as the lingua franca of politics in Turkey (Alpan, 2016: 23). Support for EU accession in the country shifted from 74\% in favor in December 2002 to $57 \%$ in favor in May 2006 (Yllmaz, 2011: 187). With the launch of EU-Turkey negotiations, the idealistic, historical-emotional rhetoric turned into a much more realistic and down-to-earth perception of the EU. 
During this period, Turkish politics was dominated by debates on charges against well-known novelists and journalists based on Article 301, and the fight over Abdullah Gül's presidency, which was seen by some circles as an AKP maneuver to further 'Islamicize' the country and to harm secular and Republican values. The picture got even more complicated with the e-memorandum released by the Turkish Chief of the General Staff in April 2007, which voiced the military's concerns over the diminishing secular values of the Republic (Grigoriadis, 2008b). Europeanization was still a significant narrative but not the indispensable goal it had been before. Rather, the AKP's emphasis on a multidimensional approach to foreign policy, and its claim to be a soft power in the region due to the country's newly assumed leadership role in the East, were the dominant narratives during this period (Çağaptay, 2009; Batalla, 2012; see also Kaya, Chapter 14). This new activism in Turkey's foreign policy created question marks about whether or not Turkey was shifting its axes away from its predominantly Western orientation toward a more Eastern-oriented foreign policy.

In this respect, identity constructions during this period rarely entailed references to 'Europe' or 'Europeanness'. 'Europe' in this period was usually used by the adversaries of EU accession in Turkey, rejuvenating the historical 'double standards' discourse, which revolves around the EU's 'insincerity' and 'insensitivity' to Turkey's priorities and values stemming from history and state tradition. For instance, Hüseyin Kuvrıkoğlu, former Chief of General Staff, accused the EU of aiming to impose on Turkey conditions similar to 'Sèvres and Lausanne', the two post-World War I agreements between Turkey (or rather the Ottoman Empire) and the European states (as cited in Bila, 2005). The latter point was raised during the Article 301 trials, where members of the European Commission, who were among the audience during the trials, were accused of trying to 'intervene in the Turkish judiciary' (Radikal, 2006).

During this period, criticism from the EU on democratic practices in Turkey continued, especially when the Turkish Constitutional Court banned two pro-Kurdish political parties, the People's Democracy Party (HADEP) in 2005 and the Democratic Society Party (DTP) in 2009, on charges of aiding the PKK and carrying out activities challenging the state. The government's reactions to the intensified EU criticism were indicative of the AKP's weakened reliance on the EU (Noutcheva \& Aydın-Düzgit, 2012: 70). To illustrate, in response to the critical report of the EP on Turkey published in 2011 (European Parliament, 2011), then Prime 
Minister Erdoğan stated that the 'Parliament is entrusted to draft the report, and we are entrusted to do as we see fit' (as cited in Milliyet Daily, 2011). At the same time, the opposition Republican People's Party's (CHP) Euroskepticism during this period was mainly 'an outcome of its distrust of the AKP government's honesty and ability in implementing the required reforms for Turkey's EU membership' (Celep, 2011: 425). Some CHP officials expressed concerns that the EU's purpose might be to maintain Turkey's candidate status forever or to treat Turkey as a second-class partner, because both scenarios served the EU's interests better (Gülmez, 2006). In either case, Europe had lost its central role within political debates, accompanied by growing skepticism and indifference in Turkish society toward Europe-even a turning away from Europe in many spheres of politics and society (Alpan, 2014: 69).

\subsubsection{Europeanization as Denial (2012-2020)}

\subsubsection{Polity: Customs Union and Migration at the Forefront}

Although the picture of Europeanization in the realm of polity after 2011 was gloomy, there were some noteworthy developments during this period. Perhaps the most important milestones in this respect came with two events: the debates on the modernization of the CU Agreement, with the intention to extend its scope beyond the manufacturing sector on the one hand, and the December 2013 Readmission Agreement followed by the March 2016 EU-Turkey Statement (also known as the EU-Turkey refugee 'deal') connected to the visa liberalization process for Turkish citizens on the other (see also Kaya, Chapter 14). The mutual willingness to cooperate on irregular migration partially revived the accession negotiations, with the opening of the chapters on 'Economic and Monetary Policy' and 'Financial and Budgetary Provisions', and was connected to an envisaged acceleration of the visa liberalization process.

The CU and its institutional structure had contributed to the EUTurkey relations and the introduction of EU-induced polity in Turkey in the previous periods, but the overall backsliding in the reform process was reflected in the operation of the $\mathrm{CU}$, as the institutional rulebased economic governance [was] weakened' in this period (Arisan-Eralp, 2018: 3). Nevertheless, the discussions on upgrading the CU started in 2014 at the initiative of the European Commission and were accelerated with the May 2015 declaration by Turkey's Economy Minister Nihat Zeybekçi and the European Commissioner for Trade Anna Cecilia 
Malmström (Arısan-Eralp, 2018: 1). Based on an impact assessment, the Commission recommended to the European Parliament and the European Council the commencement of negotiations for the modernization of the CU and 'to further extend the bilateral trade relations to areas such as services, public procurement and sustainable development' (European Commission, 2016). Although the European Parliament supported the CU revision, 'which would keep Turkey economically anchored to the EU' (European Parliament, 2019: para. 23), negotiations have not been launched as of the time of writing.

From a polity perspective, it could be argued that this period has witnessed a number of changes, and even ruptures in terms of EUTurkey institutional relations. The EU-Turkey Association Council, the main body of the $\mathrm{CU}$, which was officially designed to meet twice a year, had a meeting in March 2019 after a four years hiatus (Council of the EU, 2019). During this period, most of the institutional communication between the parties took place in the form of bilateral meetings and high level dialogue mechanisms outside the accession framework. Indeed, cooperation between the EU and Turkey was heightened in this period through the establishment of the High-Level Energy Dialogue in 2015 and High-Level Political Dialogue in 2016; the latter within the framework of the March 2016 EU-Turkey Statement. This tendency to underline the possibility of enhancing sectoral cooperation between parties without Turkey being a full EU member, thereby introducing a differentiated polity framework to EU-Turkey relations outside accession perspective, has been dubbed as 'external differentiated integration' in the academic debates on EU-Turkey relations. ${ }^{8}$

The emphasis on issue-based cooperation between the EU and Turkey also appeared in the domain of migration. A Readmission Agreement was signed in December 2013 (EU-Turkey Readmission Agreement, 2013), which also initiated the Visa Liberalization Dialogue and created a roadmap for the accomplishment of the visa liberalization between two

\footnotetext{
8 'External differentiated integration' stipulates that the EU increasingly seeks alternative models of alignment with third countries that promote non-member states' selective adoption of EU norms. For a discussion on 'external differentiated integration' and its impact on EU-Turkey relations see Turhan (2017) and Tekin (Chapter 7).
} 
parties. The March 2016 EU-Turkey Statement accelerated the fulfillment of Turkey's obligations stemming from it, but as of the time of writing, six benchmarks have yet to be fulfilled. ${ }^{\prime}$

A final highlight of this period has been the adoption of a controversial 18-article constitutional amendment package by the Turkish Parliament in January 2017, which aimed to transform Turkey from a parliamentary governance system to an executive presidency (Paul \& Seyrek, 2017). The constitutional changes, approved in the April 2017 referendum, scrapped the role of prime minister and gave the president sweeping powers, making the president the head of government as well as the head of state. The referendum results were fiercely criticized by the opposition CHP, the Peoples' Democratic Party (HDP) (BBC News, 2017), and the civil society. The EU Delegation election observers found that the referendum was unfair and not free (McIntyre, 2017), documenting in this way the limited degree of Europeanization in the process.

\subsubsection{Policy: The Continuation of Selective Europeanization}

Although it is possible to observe a high degree of compliance with EU rules and laws in Turkish legislation in the years after 2011 (European Commission, 2018), the steady decrease in the commitment to Europeanization continued in this period. Crucially, Turkey continued an approach of selective Europeanization in 'policy', following its priorities and responding to external challenges.

During this period, the government focused on various judicial reforms aimed at increasing the efficiency of the system. The EU and Turkish government launched the so-called 'Positive Agenda' in 2012 in order to revitalize EU-Turkey relations, which prioritized judicial reform as 'the most essential of all areas' (European Commission, 2012). Beyond that, in 2014 Turkey published a policy statement regarding its EU accession process, titled 'Turkey's European Union Strategy'. It aimed to promote EU harmonization efforts and accelerate 'the work in all chapters, whether politically blocked or not' (Republic of Turkey Ministry for EU Affairs, 2014: 5).

In this context, EU-related reforms continued in fields that included civil-military relations, freedom of expression and media, and the fight against corruption (Yllmaz, 2016: 94). However, in contrast to earlier

\footnotetext{
${ }^{9}$ For a detailed analysis of the EU-Turkey Readmission Agreement see Kaya (Chapter 14).
} 
reforms, the judicial reform packages of 2013 and 2014 aimed at decreasing the relative independence of the judiciary from the executive (TRT Haber, 2014). In December 2013, a governmental decree was adopted to guarantee that all forms of investigations conducted by public prosecutors can proceed only on the basis of a green light from their superiors, especially the Minister of Justice (Müftüler-Baç, 2016c: 18). Thus, the Europeanization impact continued more as a continuation of the government's political agenda rather than as an attempt of harmonization with EU legislation.

In the field of migration policy, the EU-Turkey Statement to end irregular migration from Turkey to the EU, as announced by the European Council and Turkey on 18 March 2016, re-calibrated Turkey's migration policy. The so-called refugee 'deal' stipulated that 'all new irregular migrants crossing from Turkey into Greek islands as from 20 March 2016 will be returned to Turkey' and 'for every Syrian being returned to Turkey from Greek islands, another Syrian will be resettled from Turkey to the EU taking into account the UN Vulnerability Criteria' (European Council, 2016). Besides the connection to EU accession negotiations and the visa liberalization roadmap, the arrangement implied enforced border-control measures by Turkey. However, it was subsequently subject to several disputes between the two sides, which points to the fragility and reversibility of EU-induced policies in this period.

\subsubsection{Politics: 'These Things Happen in Europe As Well'}

The AKP's landslide victory in parliamentary elections in 2011 was a turning point for the Europeanization debate and EU-Turkey relations. The crackdown on the Gezi Park protests in 2013, the government's ban on social media sites such as Twitter and YouTube in 2014, and the handling of the Ergenekon and Balyoz trials were indicative of a reversal of the Turkish government's commitment to the EU's political rules (Müftüler-Baç, 2016a: 6). The feeling of disenchantment and disappointment with the EU peaked when EU officials, again, aired alternative forms of partnership with the EU other than full membership (see also Tekin, Chapter 7), bringing back the aforementioned 'double standards' discourse. In April 2017, Commissioner for European Neighbourhood Policy and Enlargement Johannes Hahn suggested that EU member states and Turkey should initiate a more essential discussion on a 'new format for relations with Turkey' (Politico, 2017). The EU anchor moved even further away as Commission President Jean-Claude Juncker 
made it clear that no enlargement would be possible until 2019, effectively freezing Turkey's accession to the EU-while mentioning the need to 'maintain a credible enlargement perspective for the Western Balkans' (European Commission, 2017).

Nevertheless, Europe did not completely disappear from political debates and identity negotiations. Political actors made references to Europe as an 'unwanted guardian' and/or 'a partner in crime' (Alpan, 2016: 23). In particular, just before and after the 2011 parliamentary elections, then Prime Minister Erdoğan claimed that 'these things happen in Europe as well', when he was accused of being authoritarian and antidemocratic. In a speech at the Parliamentary Assembly of the Council of Europe, Erdoğan stated that he

embraced every kind of group in Turkey including Kurds, Turks, Romas. [...] But, what I see in France today is that the Roma population is being expelled. Is this democracy? I see that there is no respect for religious beliefs in France. Those who attempt to criticize Turkey should first look at themselves. (Erdoğan, 2011)

The same attitude could be sensed in Erdoğan's answers to criticisms posed against him for use of excessive force in the Gezi Park protests or when asked what would happen to those who were jailed, tried, or expelled from work after the 15 July 2016 coup attempt (The Guardian, 2017). These examples illustrate the new role of 'Europe' in the Turkish political discourse.

\subsection{Conclusion}

'Europe' has been the most popular yet most volatile buzzword in Turkish politics. Stretching from Selim the Third, the Ottoman sultan who initiated the restructuring of the Ottoman army along European lines in the eighteenth century, to Mustafa Kemal Atatürk, who saw Europe as the embodiment of civilization and constructed Turkish modernity on this premise, the emergence of 'Europe' as a journey and as a target to reach has colored Turkish political history. This intense preoccupation gained particular momentum and form with the 1963 Ankara Agreement and the 1999 Helsinki European Council decision. The academic Europeanization literature also agrees that the issue is not whether Europe matters for 
Turkey, but how it matters, to what degree, in what direction, at what point in time (Börzel, 2003).

Since 1959, the 'European impact' on Turkey has been predominantly associated with the reforms made within domestic legal and institutional structures and the overarching democratization and pluralization processes in the country. There has been considerable interest in the impact of Europeanization on particular aspects of policies and policy areas. The EU acted as a 'democratization anchor', and 'reinforcement by reward' worked as a powerful trigger for compatible reforms, in line with EU legislation (Schimmelfennig \& Sedelmeier, 2004: 662). The Europeanization process not only shaped polity, policy, and politics in Turkey but also complemented domestic, regional, and global processes.

The picture started to change after 2005, when Europeanization and the EU accession started losing salience both for the AKP government and other domestic actors, accompanied by an increase of Euroskeptic tendencies in the wider public. In the period after 2005, 'Europe' was no longer the lingua franca in the Turkish political landscape in the context of a trend that is sometimes dubbed as 'de-Europeanization' in the literature. However, this does not mean that 'Europe' completely disappeared from domestic policy orientations, political debates, and identity negotiations. Rather, the AKP used 'Europe' strategically to justify actions that the EU criticized.

Many variables, such as the unwillingness of European and Turkish leaders to foster Turkey's full EU membership, Turkey's poor score on human rights and democratization, the blockage of numerous negotiation chapters, and Europe's own perpetual crisis in economics, identity, and politics have created the impression that the Europeanization process has come to a halt for Turkey. However, as this chapter has shown, Europeanization is a versatile and complex process, covering vast areas of policy, politics, and polity, accompanied by larger domestic, regional, and global processes. This process is not limited to Turkey's EU accession. The concept of Europeanization will therefore continue to constitute a valuable point of reference for the study of the EU-orientation of polity, policy, and politics, regardless of whether Europeanization will create opportunities for new political debates, discourses, policies, and actors in the case of Turkey. 


\section{REFERENCES}

Alpan, B. (2014). Europe-as-hegemony and discourses in Turkey after 1999: What has Europeanization got to do with it? Journal of Balkan and Near Eastern Studies, 16(1), 68-85.

Alpan, B. (2015). Bir imkân olarak Avrupalılık kimliği: Türkiye-AB ilişkileri tartısmaların neresinde? Marmara Avrupa Araştırmaları Dergisi, 23(2), 5-26.

Alpan, B. (2016). From AKP's 'conservative democracy' to 'advanced democracy': Shifts and challenges in the debate on 'Europe'. South European Society and Politics, $21(1), 15-28$.

Arsan-Eralp, N. (2018). Upgrading Customs Union between Turkey and the European Union is not only about upgrading the Customs Union. TEPAV Evaluation Note.

Atikcan, E. Ö. (2010). European Union and minorities: Different paths of Europeanization? Journal of European Integration, 32(4), 375-392.

Aydın-Düzgit, S. (2016). De-Europeanisation through discourse: A critical discourse analysis of AKP's election speeches. South European Society and Politics, 21(1), 45-58.

Aydın-Düzgit, S., \& Kaliber, A. (2016). Encounters with Europe in an era of domestic and international turmoil: Is Turkey a de-Europeanising candidate country? South European Society and Politics, 21(1), 1-14.

Aydın-Düzgit, S., \& Tocci, N. (2015). Turkey and the European Union (1st ed.). London: Palgrave Macmillan.

Aytar, V. (2006). Daha karanlık bir geleceğe doğru mu? Terörle Mücadele Kanunu'nda yapilan degişiklikler. Istanbul: TESEV.

Bache, I., \& Jordan, A. (2006). Europeanisation of British politics (1st ed.). London: Palgrave Macmillan.

Bache, I., \& Marshall, A. (2004). Europeanisation and domestic change: A governance approach to institutional adaptation in Britain. Queen's Papers on Europeanisation, 5/2004.

Balfe, R. (1985). Report drawn up on behalf of the Political Affairs Committee on the human rights situation in Turkey. PE 98. 572/fin. Luxembourg: European Parliament.

Batalla, A. (2012). Turkey's foreign policy in the AKP era: Has there been a shift in the axis? Turkish Policy Quarterly, 11(3), 139-148.

BBC News. (2017, April 17). Referandumdan 'Evet' çıtı, bundan sonra ne olacak? https://www.bbc.com/turkce/haberler-turkiye-39614995. Accessed 16 May 2020.

Bila, F. (2005, December 31). Kivrıkoğlu: 'Sorun TSK değil, AB'nin çifte tutumu'. Milliyet. https://www.milliyet.com.tr/yazarlar/fikret-bila/kiv rikoglu-sorun-tsk-degil-abnin-cifte-tutumu-140500. Accessed 3 June 2020; Accessed 16 May 2020. 
Börzel, T. (2003). Environmental leaders or laggards in Europe: Why there is (not) a Southern problem (1st ed.). London: Routledge.

Börzel, T., \& Risse, T. (2003). Conceptualising the domestic impact of Europe. In K. Featherstone \& C. Radaelli (Eds.), The politics of Europeanization (1st ed., pp. 57-82). Oxford: Oxford University Press.

Börzel, T., \& Risse, T. (2009). The transformative power of Europe: The European Union and the diffusion of ideas (KFG Working Paper Series).

Bürgin, A. (2016). Why the EU still matters in Turkish domestic politics: Insights from recent reforms in migration policy. South European Society and Politics, $21(1), 105-118$.

Çağaptay, S. (2009, February 2). Turkey's turn from the West. The Washington Post.

Çalış, Ş. H. (2015). Türkiye-Avrupa Birliği ilişkileri: Kimlik arayışı, politik aktörler ve değişim (5th ed.). Ankara: Nobel Akademik Yayıncilık.

Çarkoğlu, A. (2003). Who wants full membership? Characteristics of the Turkish public support for EU membership. Turkish Studies, 4(1), 171-194.

Celep, Ö. (2011). The Republican People's Party and Turkey's EU membership. South European Society and Politics, 16(3), 423-434.

Çelik, A., \& Rumelili, B. (2006). Necessary but not sufficient: The role of the EU in resolving Turkey's Kurdish question and the Greek-Turkish conflicts. European Foreign Affairs Review, 11, 203-222.

Cizre, Ü. (2003). Demythologising the national security concept: The case of Turkey. Middle East Journal, 57(2), 213-229.

Council of the European Union. (2019, March 15). Press statement following the 54th meeting of the Association Council between the European Union and Turkey. Brussels. https://www.consilium.europa.eu/en/press/press-rel eases $/ 2019 / 03 / 15 /$ press-statement-following-the-54th-meeting-of-the-ass ociation-council-between-the-european-union-and-turkey-brussels-15-march2019/. Accessed 8 Jun 2020.

Cowles, M., Caporaso, J., \& Risse, T. (Eds.). (2001). Transforming Europe: Europeanization and domestic change (1st ed.). Ithaca: Cornell University Press.

Dedeoğlu, S., \& Elveren, A. (2008). Gender and society in Turkey: The impact of neoliberal policies, political Islam and EU accession (1st ed.). London and New York: I.B. Tauris.

Demirtaş, S. (1999, December 12). Sınır sorunları Lahey'e. Cumburiyet.

Dutz, M., Us, M., \& Yllmaz, K. (2005). Turkey's foreign direct investment challenges: Competition, the rule of law and EU accession. In B. M. Hoekman \& S. Togan (Eds.), Turkey: Economic reform and accession to the European Union (pp. 261-293). Washington, DC: World Bank. 
EC-Turkey Association Council. (1996). Decision No 1/95 of 22 December 1995 on implementing the final phase of the Customs Union. Official Journal of the European Communities, L 35/1-46, 13.2.1996.

EEC-Turkey Association Agreement. (1963). Agreement establishing an association between the European Economic Community and Turkey. Official Journal of the European Communities, L 361/29-43, 31.12.1977.

Eralp, A. (1993). Turkey and the European community in the changing postwar international system. In C. Balkır \& A. M. Williams (Eds.), Turkey and Europe (1st ed., pp. 24-44). London: Pinter.

Eralp, A. (2009). The role of temporality and interaction in the Turkey-EU relationship. New Perspectives on Turkey, 40 (Spring), 147-168.

Erdenir, B. (2015). A long and narrow road: Turkey's Europeanization process. Uluslararası İlişhiler, 12(45), 23-38.

Erdoğan, M., Bağc1, H., \& Kundakçı, S. (2008). Türkiye Büyük Millet Meclisi tutanaklarnda Türk-Yunan ilişkileri ve 'Avrupahlaşma': 1994-2006. Ankara: TBMM Basımevi.

Erdoğan, R. T. (2011, April 13). Speech at the Council of Europe Parliamentary Assembly. Available online as video at: https://www.youtube.com/watch?v= t8bQQPDGJ4I. Accessed 7 Jun 2020.

European Commission. (2004, October 6). Regular progress report on Turkey's progress towards accession. SEC(2004) 1201. Brussels.

European Commission. (2005, October 3). Negotiating framework. Luxembourg. https://ec.europa.eu/neighbourhood-enlargement/sites/near/files/ pdf/turkey/st20002_05_tr_framedoc_en.pdf. Accessed 8 Jul 2020.

European Commission. (2012, May 17). Positive EU-Turkey agenda launched in Ankara. MEMO/12/359. Brussels.

European Commission. (2016, December 21). Impact assessment accompanying the document recommendation for a Council decision authorising the opening of negotiations with Turkey on an agreement on the extension of the scope of the bilateral preferential trade relationship and on the modernisation of the Customs Union. SWD(2016) 475 final. Brussels.

European Commission. (2017, September 13). The State of the Union 2017: Catching the wind in our sails. IP/17/3164. Brussels.

European Commission. (2018, August 18). Annex to the commission implementing decision amending Commission decision C(2014) 5998 of 26 August 2014 adopting the indicative strategy paper for Turkey for the period 2014-2020, C(2018) 5067 final. Brussels.

European Commission. (2020). Turkey: Customs Unions and preferential arrangements. https://ec.europa.eu/taxation_customs/business/calculationcustoms-duties/rules-origin/customs-unions/turkey-customs-unions-prefer ential-arrangements_en. Accessed 25 Nov 2020. 
European Council. (1997). Luxembourg European Council (12 and 13 December 1997)—Presidency conclusions. https://www.consilium.europa.eu/ media/21114/luxembourg-european-council.pdf. Accessed 25 Nov 2020.

European Council. (1999). Helsinki European Council (10 and 11 December 1997)—Presidency conclusions. https://www.consilium.europa.eu/media/ 21046/helsinki-european-council-presidency-conclusions.pdf. Accessed 29 Nov 2020.

European Council. (2016, March 18). EU-Turkey statement. Press release. https://www.consilium.europa.eu/en/press/press-releases/2016/03/18/ eu-turkey-statement/. Accessed 27 Nov 2020.

European Court of Human Rights. (2010). The conscience of Europe: 50 years of the European Court of Human Rights (lst ed.). https://www.echr.coe.int/ Documents/Anni_Book_content_ENG.pdf. Accessed 27 Apr 2020.

European Parliament. (2011, March 9). European Parliament resolution of 9 March 2011 on Turkey's 2010 progress report. P7_TA(2011)0090. Strasbourg.

European Parliament. (2019, March 13). European Parliament resolution of 13 March 2019 on the 2018 Commission Report on Turkey, P8_TA (2019)0200. Strasbourg.

EU-Turkey Readmission Agreement. (2013). Agreement between the European Union and the Republic of Turkey on the readmission of persons residing without authorisation. Official Journal of the European Union, L 134/3-27, 7.5.2014.

Featherstone, K., \& Radaelli, C. (Eds.). (2003). The politics of Europeanization (lst ed.). Oxford: Oxford University Press.

Glyptis, L. (2005). The cost of rapprochement: Turkey's erratic EU dream as a clash of systematic values. Turkish Studies, 6(3), 401-420.

Grigoriadis, I. (2008a). On the Europeanisation of minority rights protection. Mediterranean Politics, 13(1), 23-41.

Grigoriadis, I. (2008b). Islam and democratisation in Turkey: Secularism and trust in a divided society. Democratization, 16(6), 1194-1213.

Gülmez, B. (2006). The Republican People's Party and Turkish foreign policy. Unpublished master's thesis, Middle East Technical University, Ankara.

Günay, D., \& Renda, K. (2014). Usages of Europe in Turkish foreign policy towards the Middle East. Journal of Balkan and Near Eastern Studies, 16(1), 47-67.

Güneş-Ayata, A. (2003). From Euroscepticism to Turkey-scepticism: Changing political attitudes on the European Union in Turkey. Journal of Europe and the Balkans, 5(2), 205-222.

Güney, A. (2015). Europeanization of civil-military relations in Turkey: Civilianization without democratization? In A. Tekin \& A. Güney (Eds.), The 
Europeanization of Turkey: Polity and politics (pp. 108-124). London: Routledge.

Hale, W., \& Özbudun, E. (2010). Islamism, democracy and liberalism in Turkey: The case of the AKP. New York: Routledge.

Hauge, H., Eralp, A., Wessels, W., \& Bedir, N. S. (2016, September). Mapping milestones and periods of past Turkey-EU relations (FEUTURE Working Paper). https://feuture.uni-koeln.de/sites/feuture/pdf/Deliverable_Narrat ives_1.2_final_neu.pdf. Accessed 20 Nov 2020.

İçduygu, A. (2015). Turkey's evolving migration policies: A Mediterranean transit stop at the doors of the EU (IAI Working Papers, 15).

Kaliber, A. (2013). Contextual and contested: Reassessing Europeanization in the case of Turkey. International Relations, 27(1), 52-73.

Kaliber, A. (2016). De-Europeanisation of civil society and public debates in Turkey: The Kurdish question revisited. South European Society and Politics, $21(1), 59-74$.

Kaya, A. (2021). Europeanization and de-Europeanization of Turkish asylum and migration policies. Chapter 14 , in this volume.

Keyman, F., \& Koyuncu, B. (2005). Globalization, alternative modernities and the political economy of Turkey. Review of International Political Economy, $12(1), 105-128$.

Kıliç, A. (2008). The gender dimension of social policy reform in Turkey: Towards equal citizenship? Social Policy and Administration, 42(5), 487-503.

Kohler-Koch, B., \& Eising, R. (Eds.). (1999). The transformation of governance in the European Union (1st ed.). London: Routledge.

Kubicek, P. (Ed.). (2003). The European Union and democratization (1st ed.). London and New York: Routledge.

Lenschow, A. (2006). Europeanisation of public policy. In J. Richardson (Ed.), European Union: Power and policy-making (3rd ed., pp. 55-71). Abingdon: Routledge.

McIntyre, N. (2017, April 17). EU observer in Turkey condemns referendum as 'neither fair nor free'. Independent. https://www.independent.co.uk/news/ world/asia/eu-observer-turkey-condemns-referendum-result-president-erd ogan-opposition-parties-demand-recount-a7686876.html. Accessed 17 May 2020.

Milliyet Daily. (2011, March 11). We will do as we see fit.

Moga, T. (2010). Connecting the enlargement process with the Europeanisation theory: The case of Turkey. CES Working Papers, 2(1), 47-61.

Müftüler-Baç, M. (2016a). The European Union and Turkey: Transforming the European periphery into European borderlands (EIU Working Papers, 12).

Müftüler-Baç, M. (2016b). Turkey's ambivalent relationship with the European Union: To accede or not to accede. Uluslararası İlişskiler, 13(52), 89-103. 
Müftüler-Baç, M. (2016c). Judicial reform in Turkey and the EU's political conditionality: (Mis)Fit between domestic preferences and EU demands (MAXCAP Papers, 18).

Müftüler-Baç, M., \& Gürsoy, Y. (2010). Is there a Europeanisation of Turkish foreign policy? An addendum to the literature on EU candidates. Turkish Studies, $11(3), 405-427$.

Munyar, V. (2002, October 7). Diyarbakır'ı AB'ye kim taşıyacak. Hürriyet. https://www.hurriyet.com.tr/diyarbakiri-abye-kim-tasiyacak-102077.

Accessed 17 May 2020.

Nas, C.. (2012). Europeanisation of identity: The case of the rebuffed candidate. In C. Nas \& Y. Özer (Eds.), Turkey and the European Union: Processes of Europeanization (1st ed., pp. 23-44). Farnham: Ashgate.

Neziroğlu, İ., \& Yılmaz, T. (2013). Hükümetler, programlar ve genel kurul göriusmeleri cilt 9 - (30 Ekim 1995-11 Ocak 1999). Ankara: TBMM Basımevi.

Noutcheva, G., \& Aydın-Düzgit, S. (2012). Lost in Europeanization? The Western Balkans and Turkey. West European Politics, 35(1), 59-78.

Olsen, J. (2002). The many faces of Europeanisation. Journal of Common Market Studies, 40(5), 921-952.

Öniş, Z. (2003). Domestic politics, international norms and challenges to the state: Turkey-EU relations in the post-Helsinki era. Turkish Studies, 4(1), 9-34.

Özbudun, E. (2015). Turkey's judiciary and the drift toward competitive authoritarianism. The International Spectator, 50(2), 42-55.

Özdemir, B. (2014). The role of the EU in Turkey's legislative reforms for eliminating violence against women: A bottom-up approach. Journal of Balkan and Near Eastern Studies, 16(1), 119-136.

Park, W. (2000). Turkey's European Union candidacy: From Luxembourg to Helsinki-To Ankara? Mediterrannean Politics, 5(3), 31-53.

Paul, A., \& Seyrek, M. (2017, January 24). Constitutional changes in Turkey: A presidential system or the president's system? European Policy Centre Commentary.

Politico. (2017). POLITICO Brussels Playbook presented by Danfoss: Macromania-Turkey reboot-Climate consensus. https://www.politico.eu/newsle tter/brussels-playbook/politico-brussels-playbook-presented-by-danfoss-mac romania-turkey-reboot-climate-consensus/. Accessed 20 Nov 2020.

Radaelli, C. (2003). The Europeanisation of public policy. In K. Featherstone \& C. Radaelli (Eds.), The politics of Europeanization (1st ed.). Oxford: Oxford University Press.

Radaelli, C. (2004). Europeanisation: Solution or problem? European Integration Online Paper, 8(16). http://www.eiop.or.at/eiop/pdf/2004-016.pdf. Accessed 28 May 2020. 
Radaelli, C., \& Pasquier, R. (2006). Conceptual issues. In P. Graziano \& M. Vink (Eds.), Europeanization: New research agendas (pp. 35-45). Basingstoke: Palgrave Macmillan.

Radikal. (2002a, March 5). Ismail Cem patlad.

Radikal. (2002b, August 20). Yeni Türkiye Avrupa yolunda.

Radikal. (2003, April 26). Brüksel'de neler olmuş neler. http://www.radikal.com. tr/politika/brukselde-neler-olmus-neler-667949/. Accessed 16 June 2020.

Radikal. (2004, December 15). Asla boyun eğmeyiz.

Radikal. (2006, February 8). Mabkeme salonunda Ülkücüler terör estirdi.

Republic of Turkey Ministry for EU Affairs. (2014). Turkey's new European Union strategy: Determination in the political reform process, continuity in socio-economic transformation, effectiveness in communication. https://www. ab.gov.tr/files/pub/turkeys_new_eu_strategy.pdf. Accessed 25 Nov 2020.

Republic of Turkey Ministry of Foreign Affairs. (2007). Political reforms in Turkey (1st ed.). Ankara: Secretariat General for EU Affairs.

Rumelili, B. (2008). Negotiating Europe: EU-Turkey relations from an identity perspective. Insight Turkey, 10(1), 97-110.

Rumford, C. (2003). Resisting globalization? Turkey-EU relations and human and political rights in the context of cosmopolitan democratization. International Sociology, 18(2), 379-394.

Saatçioğlu, B. (2014). AKP's 'Europeanization' in civilianization, rule of law and fundamental freedoms: The primacy of domestic politics. Journal of Balkan and Near Eastern Studies, 16(1), 86-101.

Saatçioğlu, B. (2016). De-Europeanisation in Turkey: The case of the rule of law. South European Society and Politics, 21(1), 133-146.

Schimmelfennig, F., Engert, S., \& Knobel, H. (2002). The conditions of conditionality: The impact of the EU on democracy and buman rights in European non-member states. Paper Presented at ECPR Joint Session of Workshops, Turin.

Schimmelfennig, F., Engert, S., \& Knobel, H. (2003). Costs, commitment and compliance: The impact of EU democratic conditionality on Latvia, Slovakia and Turkey. Journal of Common Market Studies, 41(3), 495-518.

Schimmelfennig, F., Engert, S., \& Knobel, H. (2006). International socialization in Europe: European organizations, political conditionality and democratic change. Basingstoke: Palgrave Macmillan.

Schimmelfennig, F., \& Sedelmeier, U. (2004). Governance by conditionality: EU rule transfer to the candidate countries of Central and Eastern Europe. Journal of European Public Policy, 11(4), 661-679.

Schimmelfennig, F., \& Sedelmeier, U. (Eds.). (2005). The Europeanization of Central and Eastern Europe. Ithaca: Cornell University Press.

Tekin, F. (2021). Differentiated integration: An alternative conceptualization of EU-Turkey relations. Chapter 7, in this volume. 
Terzi, Ö. (2012). Europeanisation of Turkish foreign policy after more than ten years of EU candidacy. In Ç. Nas \& Y. Özer (Eds.), Turkey and the EU: Processes of Europeanisation (1st ed.). Farnham: Ashgate.

The Guardian. (2017, July 15). Turkey, a year after the attempted coup, is defending democratic values. https://www.theguardian.com/commen tisfree/2017/jul/15/turkey-coup-democracy-recep-tayyip-erdogan. Accessed 16 June 2020.

Torun, Z. (2021). From convergence to divergence: The compatibility of Turkish and EU foreign policy. Chapter 13, in this volume.

TRT Haber. (2014, January 24). Başbakan Erdoğan'dan HSYK açıklaması. https://www.trthaber.com/haber/gundem/basbakan-erdogandan-hsyk-aci klamasi-116254.html. Accessed 28 Nov 2020.

Turhan, E. (2017, July 3). Thinking out of the accession box: The potential and limitations of internal and external differentiated integration between Turkey and the EU (CIFE Policy Paper No. 58). https://www.cife.eu/Ressou rces/FCK/files/publications/policy\%20paper/CIFE_Policy_Paper_58_Thi nking_out_of_The_Accession_Box_EU_Turkey_Ebru_Turhan_2017_l.pdf. Accessed 28 Nov 2020.

Turhan, E., \& Reiners, W. (2021). Unpacking the new complexities of EUTurkey relations: Merging theories, institutions, and policies. Chapter 1, in this volume.

Yetkin, M. (2005, October 4). Önümüzde zor günler var. Radikal.

Yilmaz, G. (2014). It is pull-and-push that matters for external Europeanization! Explaining minority policy change in Turkey. Mediterranean Politics, 19(2), 238-258.

Yllmaz, G. (2016). From Europeanization to de-Europeanization: The Europeanization process of Turkey in 1999-2014. Journal of Contemporary European Studies, 24(1), 86-100.

Yilmaz, G. (2017). Minority rights in Turkey: A battlefield for Europeanization (1st ed.). London: Routledge.

Yilmaz, H. (2011). Euroscepticism in Turkey: Parties, elites, and public opinion. South European Society and Politics, 16(1), 185-208.

Başak Alpan is associate professor and lecturer in European politics and political sociology at the Center for European Studies and the Department of Political Science and Public Administration at the Middle East Technical University (METU), Ankara, Turkey. She holds a Ph.D. from the University of Birmingham. She conducts research and publishes on European integration, discourse theory, post-structuralism, EU-Turkey relations, and football and identity. Alpan worked in many EU-funded projects as a researcher and coordinator, including FREE (Football Research in an Enlarged Europe), FEUTURE (The Future of Turkey-EU Relations) and LEAP (Linking to Europe at the Periphery). 
Open Access This chapter is licensed under the terms of the Creative Commons Attribution 4.0 International License (http://creativecommons.org/licenses/ by $/ 4.0 /$ ), which permits use, sharing, adaptation, distribution and reproduction in any medium or format, as long as you give appropriate credit to the original author(s) and the source, provide a link to the Creative Commons license and indicate if changes were made.

The images or other third party material in this chapter are included in the chapter's Creative Commons license, unless indicated otherwise in a credit line to the material. If material is not included in the chapter's Creative Commons license and your intended use is not permitted by statutory regulation or exceeds the permitted use, you will need to obtain permission directly from the copyright holder.

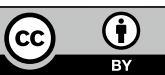

